\title{
大学生における被害妄想的観念への 対処方略について
}

\author{
森本幸子 ${ }^{1}$ 埼玉工業大学
}

\author{
Coping for paranoid ideation in college students
}

Sachiko Morimoto (Saitama Institute of Technology)

\begin{abstract}
Research has shown that individual with a high level of paranoia use more avoidant coping strategies (Ellett, Lopes, \& Chadwick, 2003). The present study examines coping strategies in 141 college students with lower or higher levels of paranoid ideation using the Paranoia Scale (Fenigstein \& Vanable, 1992) and the Interpersonal Stress Coping Inventory (ISI; Kato, 2000). Participants were first required to complete the ISI for paranoid ideation (ISI-pre). They were then asked to complete ISI again (ISI-post) on the assumption that the previous coping strategies (ISI-pre) did not work well. The results showed that people with a higher level of paranoid ideation reported more negative relationship-oriented strategies on both the ISI-pre and ISI-post. The ISI-pre was higher than ISI post for positive relationship-oriented strategies among the participants with a higher level of paranoid ideation. These results suggested that people with paranoid ideation keep using the negative relationshiporiented strategies and reduce positive relationship-oriented strategies, if the primary coping strategies do not work well.
\end{abstract}

Key words: paranoid ideation, non clinical population, avoidant coping.

The Japanese Journal of Psychology

2008, Vol. 78, No. 6, pp. 607-612

ここ数年, 健常者を対象とした妄想的観念の研究が 活発に行われており，妄想的観念は不安や抑うつの症 状と同じように健常者に扔いてもよく見られる現象で あることが報告されている（Van Os \& Verdoux, 2003)。妄想的観念は，不合理な確信や観念であるも のの, 妄想の場合ほど強固に保持されないと定義され る (American Psychiatric Association, 1994)。Strauss (1969) が，妄想がある，あるいは妄想がないといっ た二分法的な分類では実際の妄想を捉えきれず，妄想 が普通の信念の連続線上に位置するのではないかと指 摘して以来, 妄想的観念に関する研究が行われるよう になった。数千人を対象に健常者の妄想的観念につい て調べた研究などから，Strauss（1969）の指摘どお り，健常者においても妄想的観念が見られることが明 らかとなり, 妄想的観念と妄想との連続性を示唆する 結果が得られている (Van Os, Hanssen, Bijl, \& Ravelli, 2000)。健常者の妄想的観念の多くは被害的な内容 (被害妄想的観念) である。被害妄想的観念の体験率

Correspondence concerning this article should be sent to: Sachiko Morimoto, Sendai Shirayuri Women's College, Honda-cho, Izumi-ku, Sendai 981-3107, Japan (e-mail: s-morimoto@sendai-shirayuri.ac.jp)

1 現所属 : 仙台白百合女子大学
については, Ellett, Lopes, \& Chadwick (2003) が行つ た研究では, 健常者である調査対象者の $47 \%$ がこれ までに被害妄想的観念を持ったことがあると報告して いる。Johns, Cannon, Singleton, Murray, Farrell, Brugha, Bebbington, Jenkins, \& Meltzer（2004）もまた, 健常者 を対象にした研究において, 調査対象者の約 $21 \%$ は, 過去に被害妄想的観念を持ったことがあると回答した ことを報告しており, 被害妄想的観念は多くの健常者 に見られる現象であることがわかる。

これまでに, 健常者の被害妄想的観念がどのように 形成されるのかについてはある程度研究が行われてい る (Martin \& Penn, 2001; 森本・丹野, 2004)。では, 被害妄想的観念はどのように維持されるのだろうか。 被害妄想の研究では, 妄想に関連する苦痛を減らすた めに回避行動をとることにより（例：人に悪口を言わ れていると感じるので, 人に会うことを避けたり人が 集まる場所を避ける)，妄想の内容が正しいのかどう かを確認する機会を逸してしまい，その結果として妄 想が維持されると考えられている (Freeman, Garety, \& Kuipers, 2001)。健常者を対象にした研究でも, 被害 妄想的観念を持つ人は回避行動をとりやすいことが報 告されている。被害妄想的観念への対処法に関して自 
由記述調査を行った研究では, 被害妄想的観念を持つ 学生のうち $44 \%$ が被害妄想的観念を抱かせる人や状 況に対応したいと思いながらも, 実際に人などと直接 関わるような対処行動をとったと回答した学生は $23 \%$ あり， $35 \%$ の学生は実際には何の対処もしてお らず，22\%は被害妄想的観念を抱かせるような状況や 人を避けていると回答している (Ellett et al., 2003)。 また, 被害妄想的観念が強い人ほぼ, 情動的対処行動 や回避的対処行動を用いており, 合理的な対処行動な ぞを用いない傾向があることも報告されている (Freeman, Garety, Bebbington, Smith, Rollinson, Fowler, Kuipers, Ray, \& Dunn, 2005)。これらの先行研究では, 被害妄想と同様に, 回避的対処方略が被害妄想的観念 の維持に関与していると考えられている。

ところで, 対処方略に関する研究は, Lazarus \& Folkman（1984 本明・春木・織田監訳，1991）を中 心に発展し, 現在では対処方略の構造や測定法, その 効果や安定性など様々な側面において研究が行われて いる。これらの研究結果から, 回避的な対処方略はス トレス反応の低減にあまり効果がない不適切な対処方 略であると考えられている。問題焦点型対処方略は, 不安や抑うつなどを緩和する効果を持つが, 情動焦点 型対処方略は不安や抑うつを増悪させることが知られ ている。したがって, 被害妄想的観念に対して情動的 または回避的な対処方略をとることは, 状況を悪化さ せてしまい，より一層被害妄想的観念を増悪させるこ とが予想されるかもしれない。しかし, Forsythe \& Compas（1987）によって, コントロール可能な状況 に対して問題解決的な対処方略を用い, コントロール 可能性が低い状況に対して情動焦点型の対処方略を使 用することがストレス反応の軽滅に有効であることが 指摘されている。被害妄想的観念をいだくような状況 は必ずしもコントロール可能な状況ばかりではなく, むしろ自分ではどうすることもできない状況もあるだ ろう。よって, 被害妄想的観念への情動焦点的な対処 方略や回避的な対処方略が必ずしも不適切であるとは 言い切れないのではないだろうか。

われわれはストレス状況下に拀いて様々な工夫をし ながら対処方略の選択を行っている。例えば, “バス が遅れており約束の時間に遅刻しそうだ”といった状 況では, バスに乗車することを諦めてタクシーに乗車 するかもしれない。またタクシーに乗車できなけれ ば，電車などの他の交通機関を利用したり，それでも 間に合わないようであれば，前もって約束の相手に連 絡をとろうとするかもしれない。このようにある対処 方略を用いても望んだ結果を得られなければ, 次に別 の対処方略を用いるだろう。使用した対処方略によっ て望んでいた結果を得られない状況をコーピング失敗 状況とし，コーピング失敗状況において, 望ましい結 果を得るために効果がなかった対処方略ではなく, 別 の新しい対処方略を用いることを加藤（2001a）はコ 一ピングの柔軟性と定義している。大学生を対象に調 查を行い, コーピングの柔軟性に乏しい者は抑うつ傾 向が強いことを明らかにしている。加藤 (2001a) は, どのような対処方略を用いるのかということよりも, むしろ，ある対処方略を用いても状況が変わらないと きにどのように用いる対処方略を変更するのかという 点が重要であると述べている。これまでの被害妄想的 観念への対処方略に関する研究において, このような 視点によって検討を行っているものはない。そこで本 研究では, 大学生を対象に, 被害妄想的観念を持つ者 はどのような対処方略を用いるのか，そして，その対 処方略によって望むような結果を得られないときに, どのように用いる対処方略を変更するのかという点に ついて検討することを目的とした。

\section{方 法}

\section{調査対象者}

調査に参加したのは, 首都圈の大学に通う大学生 141 名（男性 103 名, 女性 38 名）であり, 平均年齢 は 19.58 歳 $(S D=1.18)$ であった。

\section{手続き}

大学における講義を利用して質問紙調查を実施し た。

\section{質問紙}

被害妄想的観念 パラノイア尺度 (Fenigstein \& Vanable, 1992) の日本語版 (丹野 - 石垣 $\cdot$ 大勝・杉 浦，2000）を使用した。これは，20項目（例：見知 らぬ人が批判的な目で私を見ていると感じることがよ くある）より構成される尺度であり, 調査対象者に は, 各項目に対して“大変よく当てはまる”から“全 く当てはまらない”までの 5 件法で回答を求めた。

ストレスコーピング 対人コーピング尺度（加藤, 2000）を使用した。これは大学生を対象として開発さ れた尺度であり, 友人関係に起因するストレスフルな イベントに対するコーピングの個人差を測定する尺度 である。ネガティブ関係コーピング（例：無視するよ うにした), ポジティブ関係コーピング (例：積極的 に話をするようにした), 解決先送りコーピング （例：何もせず自然の成り行きにまかせた）の三つの 下位尺度の合計 34 項目から構成される。本研究では, 加藤 (2001a) を参考に対人コーピング尺度の各下位 尺度から 5 項目ずつ, 合計 15 項目を使用した。まず 最初に“前のページ（パラノイア尺度）の質問項目の ようなことを感じるときに，あなたは普段どのように 考えたり行動したりしていますか”のように教示し, 被害妄想的観念に対する対処方略について回答するよ 
うに求めた (プレ条件)。続いて，“そのようなことを 行っても，皆さんが望んでいるような結果が得られな かったとき，皆さんはどのように考えたり，行動した りしますか”と教示して上記で使用したものと同じ 15 項目に対して回答を求めた（ポスト条件）。なお, 対人コーピング尺度の項目配列順序についても加藤 （2001a）を参考にしてプレ条件とポスト条件では配列 順序を変更した。対人コーピング尺度では, “ょくあ てはまる”から“あてはまらない”までの 4 件法で回 答を求め, 各項目の得点を $3-0$ 点とした。

\section{結果}

被害妄想的観念と対人コーピングの基本統計量を Table 1 に示した。Table 2 には, 変数間の相関係数 を示した。被害妄想的観念と対人コーピングとの相関 係数を検討したところ, 被害妄想的観念とネガティブ 関係コーピングとの間に弱い正の相関が見られたが, それ以外の対人コーピングとの間には相関は見られな かった。

次に, 被害妄想的観念の平均值によって被害妄想的 観念高低群に分け, 各群において, プレ条件とポスト 条件で用いる対人コーピングが異なるのかどうかを検 討した。被害妄想的観念 $\times$ 対人コーピングの種類 $\times$ 対 人コーピングの時期の 3 要因の分散分析を行った。各 群における対人コーピング得点を Table 3 に示した。 分析の結果, 二次の交互作用が有意であった $(F(2$, $278)=3.11, p<.05)$ 。そこで, 被害妄想的観念得点の 高低群ごとに対人コーピングの種類 $\times$ 対人コーピング の時期の単純交互作用を分析した。その結果, 被害妄 想的観念低群においては, 対人コーピングの種類の主 効果のみが有意であった $(F(2,140)=33.03, p<.01)$ 。 LSD 法による多重比較を行ったところ, 解決先送り コーピング，ポジティブ関係コーピング，ネガティブ 関係コーピングの順に多く用いられていることがわか った $(p<.05)$ 。一方被害妄想的観念高群では, 対人 コーピングの種類と時期の交互作用が有意傾向であっ た $(F(2,138)=2.47, p<.10)$ 。単純主効果の検定を行 ったところ，プレ条件ならびにポスト条件における対 人ストレスコーピングの種類の単純主効果が有意であ つた $(F(2,138)=17.08, p<.01 ; F(2,138)=17.48$, $p<.01)$ 。LSD 法を用いた多重比較の結果，プレ条件 でもポスト条件でも, 解決先送りコーピングを一番よ く用いていることがわかった。ポジティブ関係コーピ ングとネガティブ関係コーピングの間に差異は見られ なかった。また，ポジティブ関係コーピングにおける 時期の単純主効果が有意であった $(F(1,139)=4.32$, $p<.05)$ 。プレ条件よりもポスト条件のポジティブ関 係コーピング得点が低かった。以上の結果をまとめる と, 被害妄想的観念高低群ともに, 解決先送りコーピ ングを最も多く用いていることがわかった。また, 被
Table 1

Summary of descriptive statistics for each variables

\begin{tabular}{lccc}
\hline & $M$ & $S D$ & Range \\
\hline Paranoid ideation & 46.48 & 14.26 & $20-1000$ \\
$\begin{array}{l}\text { Interpersonal stress coping } \\
\text { (ISI-pre) }\end{array}$ & & & \\
$\quad$ NRS & 9.17 & 3.31 & $0-45$ \\
$\quad$ PRS & 10.16 & 3.20 & $0-45$ \\
$\quad$ PSC & 12.62 & 3.10 & $0-45$ \\
Interpersonal stress coping & & & \\
(ISI-post) & & & \\
$\quad$ NRS & 9.13 & 3.52 & $0-45$ \\
$\quad$ PRS & 9.87 & 3.43 & $0-45$ \\
$\quad$ PSC & 12.39 & 3.40 & $0-45$ \\
\hline
\end{tabular}

Note. NRS: Negative relationship-oriented strategies; PRS: Positive relationship-oriented strategies; PSC: Postponed-solution coping.

害妄想的観念高群は，先に用いた対処方略が功を奏せ ず新たに対処方略を用いるときに，対処方略をポジテ イブ関係コーピングに変容させにくいことがわかっ た。

次に, 対人コーピングの種類ごとに, 被害妄想的観 念 $\times$ 対人コーピングの時期の単純交互作用を分析し た。その結果, ネガティブ関係コーピングについて は, 被害妄想的観念群の主効果が有意であった $(F(1$, $139)=10.79, p<.01)$ 。被害妄想的観念高群の方が低 群よりもネガティブ関係コーピングの得点が高かっ た。その他の主効果と交互作用は有意ではなかった。 ポジティブ関係コーピングと解決先送りコーピングで は, 主効果と交互作用はいずれも有意ではなかった。

\section{考察}

本研究では，対処の柔軟性という視点から被害妄想 的観念への対処方略について検討を行った。まず最初 に, 被害妄想的観念に対する対処方略を検討した結 果, 被害妄想的観念高群は低群と比べて, ネガティブ 関係コーピングを多く用いることがわかった。この結 果は, Ellett et al. (2003) の結果と一致すると考えら れる。本研究で用いた対人コーピング尺度のうち，ネ ガティブ関係コーピングは “人や状況の回避”に相当 する。先行研究と同様に, 本研究の結果は, 被害妄想 的観念高得点者は，低得点者に比べて回避的な対処方 略を用いることが多いことを示唆するものであった。 しかし, 被害妄想的観念高群では, プレ条件, ポスト 条件共に解決先送りコーピングを一番多く用いてお り，ポジティブ関係コーピングとネガティブ関係コー ピングの間に差は見られなかった。よって, 被害妄想 的観念高群は，回避的な対処方略と同程度に，被害妄 
Table 2

Correlation matrix for each variables

\begin{tabular}{|c|c|c|c|c|c|c|c|}
\hline & \multirow{3}{*}{$\begin{array}{l}\text { Paranoid } \\
\text { ideation }\end{array}$} & \multicolumn{6}{|c|}{ Interpersonal stress coping } \\
\hline & & \multicolumn{3}{|c|}{ ISI-pre } & \multicolumn{3}{|c|}{ ISI-post } \\
\hline & & NRS & PRS & PSC & NRS & PRS & PSC \\
\hline \multicolumn{2}{|c|}{ Paranoid ideation } & $.187^{*}$ & .050 & .015 & $.267^{* *}$ & -.036 & .100 \\
\hline \multicolumn{8}{|c|}{ Interpersonal stress coping } \\
\hline \multirow[t]{3}{*}{ ISI-pre } & NRS & & $-.260^{* *}$ & $.340^{* *}$ & $.818^{* *}$ & $-.269^{* *}$ & $.320^{* *}$ \\
\hline & PRS & & & -.098 & $-.191^{*}$ & $.811^{* *}$ & -.064 \\
\hline & PSC & & & & $.344^{* *}$ & -.115 & $.733^{* *}$ \\
\hline \multirow[t]{3}{*}{ ISI-post } & NRS & & & & & $-.210^{*}$ & $.432^{* *}$ \\
\hline & PRS & & & & & & -.034 \\
\hline & PSC & & & & & & \\
\hline
\end{tabular}

Note. NRS: Negative relationship-oriented strategies; PRS: Positive relationship-oriented strategies; PSC: Postponed-solution coping. ${ }^{* *} p<.01$, ${ }^{*} p<.05$

Table 3

Mean and $S D$ of Interpersonal stress coping for each group

\begin{tabular}{lrrrr}
\hline & \multicolumn{4}{c}{ Paranoid ideation } \\
\cline { 2 - 5 } & Low $(n=71)$ & \multicolumn{2}{c}{$\operatorname{High}(n=70)$} \\
& $M$ & $S D$ & $M$ & $S D$ \\
\hline Interpersonal stress coping & & & & \\
$\quad($ ISI-pre) & & & & \\
NRS & 8.42 & 2.67 & 9.93 & 3.68 \\
PRS & 10.30 & 3.28 & 10.03 & 3.10 \\
PSC & 12.44 & 2.98 & 12.81 & 3.19 \\
Interpersonal stress coping & & & & \\
$\quad$ (ISI-post) & & & & \\
NRS & 8.14 & 2.77 & 10.14 & 3.87 \\
PRS & 10.25 & 3.44 & 9.47 & 3.35 \\
PSC & 11.93 & 3.15 & 12.85 & 3.55 \\
\hline
\end{tabular}

Note. NRS: Negative relationship-oriented strategies; PRS: Positive relationship-oriented strategies; PSC: Postponed-solution coping.

想的観念を生じさせる状況や人と関わるような積極的 な対処方略も使用していることが明らかとなった。解 決先送りコーピングについては，心理的ストレス反応 を軽減する効果があると報告されているため（加藤, 2001b), 被害妄想的観念低群のみならず高群でも解決 先送りコーピングを一番多く使用していたという本研 究の結果は, 両群共にストレス低減に効果的な対処方 略を一番多く用いていたと考えられるかもしれない。 しかし, 最近の研究において, 相手との関係性の志向 タイプによって解決先送りコーピングがもたらす影響 が異なることが明らかにされている（加藤，2006）。 例えば，相手と深く広く付き合いたい，または浅く広 く付き合いたいと考えている人では解決先送りコーピ ングと否定的対人感情との間に負の相関が見られた が，相手と浅く狭く付き合いたいと考えている人で
は，解決先送りコーピングと否定的対人感情との間に 正の相関が得られている。被害妄想的観念低群では, ネガティブ関係コーピングよりもポジティブ関係コー ピングを用いることが多いため，積極的に対人関係の 修復に努め，比較的良好な対人関係を維持しているか もしれない。一方, 被害妄想的観高群では, 低群に比 べてネガティブ関係コーピングを使用することが多い ため, 対人関係が悪化し, 親密な関係を形成すること が難しい状況になりやすいかもしれない。両群を取り 巻く対人状況が異なる場合には, 一概に解決先送りコ ーピングの使用がストレス反応を低減するとは言い切 れないだろう。この点については, 今後詳細に検討す る必要がある。

次に，使用したコーピングによって望んでいた結果 が得られない状況下で, 被害妄想的観念に対してぞの ような対処方略を用いるのかという視点から検討を行 つた。その結果, 被害妄想的観念低群では, 使用した 対処方略に変化は見られなかった。一方，被害妄想的 観念高群では, ポジティブ関係コーピングの得点が, プレ条件と比べてポスト条件の方が低かった。つま り, 被害妄想的観念を思い浮かべる回数の多い人で は，最初に用いた対処方略が功を奏さない場合には， その後は積極的に他人と関わって問題を解決しようと するような対処方略をあまり用いなくなることがわか つた。このように, 本研究の結果, 対処方略を変化さ せたという点では被害妄想的観念高群の方が柔軟に対 応しているとも考觉られる。しかし，ポスト条件にお けるポジティブ関係コーピングの減少は, 使用した対 処方略に占める能動的な対処方略の割合が減少したこ とを意味するだろう。対処方略の効果に関する研究で は，コーピングレパートリーも重要視されており，コ ーピングレパートリーが豊富であるほどストレス低減 に効果的であることが指摘されている（Westman \& 
Shirom, 1995)。したがって，コーピングレパートリー という点から考えると, 被害妄想的観念高群はある対 処方略がストレス低減に功を奏しないときに, 次に用 いる対処方略の多くがネガティブ関係コーピングや解 決先送りコーピングのような受動的な対処方略となる ことから，コーピングレパートリーを狭めてしまうこ とが示唆された。

本研究の結果, 先行研究で指摘されているように, 被害妄想的観念低群と比較すると, 高群では回避的な コーピングを多く用いていた。しかし，解決先送りコ ーピングや積極的なコーピングも用いていることがわ かった。そして，これらのコーピングが功を奏しない ときには，より受動的なコーピングを中心的に用いる ようになることが明らかとなった。被害妄想的観念低 群ではプレ条件とポスト条件を通して用いるコーピン グの内容や量に変化は見られなかったことを考慮する と一概には言えないが, 従来考えられているように回 避的コーピングを使用することのみが被害妄想的観念 を維持させるのではなく, 最初に用いたコーピングに よって望んでいた結果が得られないときに, その次に より一層受動的なコーピングを多く用いるようにな り，コーピングレパートリーを狭めてしまうことも被 害妄想的観念の維持に関係しているのかもしれない。 しかしながら, 本研究は横断研究であるため, 用いた 対処方略が被害妄想的観念の維持に関与するのかぞう かについては明らかにすることができない。先行研究 では, 期待した効果が得られなかった対処方略の後に ぞのように対処方略が変化するのかについて調査対象 者を分類して抑うつとの関連を検討している（加藤, 2001a)。したがって, 今後は, 先行研究のように, 調 査対象者ごとに対処方略の変化について分類を行った り, 縦断調査を用いて対処方略の影響について検討す ることが必要だろう。

\section{引用文献}

American Psychiatric Association (1994). Diagnostic and statistical manual of mental disorders. 4th ed. Washington, D. C.: American Psychiatric Association.

Ellett, L., Lopes, B., \& Chadwick, P. (2003). Paranoia in a nonclinical population of college students. Journal of Nervous and Mental Disease, 191, 425-430.

Fenigstein, A., \& Vanable, P. A. (1992). Paranoia and selfconsciousness. Journal of Personality and Social Psychology, 62, 129-138.

Forsythe, C., \& Compas, B. E. (1987). Interaction of cognitive appraisal of stressful events and coping: Testing the goodness of fit hypothesis. Cognitive Therapy and Research, 11, 473-485.

Freeman, D., Garety, P. A., Bebbington, P. E., Smith, B., Rollinson, R., Fowler, D., Kuipers, E., Ray, K., \& Dunn, G. (2005). Psychological investigation of the structure of paranoia in a non-clinical population. British Journal of Psychiatry, 186, 427-435.

Freeman, D., Garety, P. A., \& Kuipers, E. (2001). Persecutory delusions: Developing the understanding of belief maintenance and emotional distress. Psychological Medicine, 31, 1293-1306.

Johns, L. C., Cannon, M., Singleton, N., Murray, R. M., Farrell, M., Brugha, T., Bebbington, P., Jenkins, R., \& Meltzer, H. (2004). Prevalence and correlates of selfreported psychotic symptoms in the British population. British Journal of Psychiatry, 185, 298-305.

加藤 司 (2000). 大学生用対人ストレスコーピング 尺度の作成 教育心理学研究，48，225-234.

(Kato, T. (2000). Construction of the interpersonal stress-coping inventory for undergraduates. Japanese Journal of Educational Psychology, 48, 225-234.)

加藤 司 (2001a)。コーピングの柔軟性と抑うつ傾向 との関係 心理学研究, 72, 57-63.

(Kato, T. (2001a). The relationship between flexibility of coping to stress and depression. Japanese Journal of Psychology, 72, 57-63.)

加藤 司 $(2001 b)$. 対人ストレス過程における帰属と コーピング 性格心理学研究, 9, 148-149.

(Kato, T. (2001b). The roles of attribution and coping behavior in interpersonal stress process. Japanese Journal of Personality, 9, 148-149.)

加藤 司 (2006). 対人ストレス過程に打ける友人関 係目標 教育心理学研究, 54, 312-321.

(Kato, T. (2006). Role of friendship in the processes of interpersonal stress among college students. Japanese Journal of Educational Psychology, 54, 312321.)

Lazarus, R. S., \& Folkman, S. (1984). Stress, appraisal, and coping. New York: Springer.

(ラザルス， R.S.・フォルクマン，S．本明 寛・ 春木 豊・織田正美（監訳）（1991）。ストレスの 心理学 実務教育出版)

Martin, J. A., \& Penn, D. L. (2001). Brief report social cognition and subclinical paranoid ideation. British Journal of Clinical Psychology, 40, 261-265.

森本幸子・丹野義彦（2004）。大学生における被害妄 想的観念に関する研究一一素因ストレスモデルを 用いて—— 心理学研究, 75, 118-124.

(Morimoto, S., \& Tanno, Y. (2004). A study of paranoid ideation in college students: An approach with the diathesis-stress model. Japanese Journal of Psychology, 75, 118-124.)

Strauss, J. S. (1969). Hallucinations and delusions as points on continua function. Archives of General Psychiatry, 49, 624-629.

丹野義彦・石垣玩麿 - 大勝裕子・杉浦義典 (2000). パラノイア尺度の信頼性このはな心理臨床ジャ ーナル, 5, 93-100.

(Tanno, Y., Ishigaki, T., Okatsu, Y., \& Sugiura, Y. (2000). Reliability of paranoia scale. Journal of Konohana Journal of Clinical Psychology, 5, 93-100.)

Van Os, J., Hanssen, M., Bijl, R. V., \& Ravelli, A. (2000). Revisited: A psychosis continuum in the general 
population? Schizophrenia Research, 45, 11-20.

Van Os, J., \& Verdoux, H. (2003). Diagnosis and classification of schizophrenia: Categories versus dimensions, distributions versus disease. In R. M. Murray, P. B. Jones, E. Susser, J. Van Os, \& M. Cannon (Eds.), The Epidemiology of schizophrenia. Cambridge: Cambridge University Press. pp. 364-
410.

Westman, M., \& Shirom, A. (1995). Dimensions of coping behavior: A proposed conceptual framework. Anxiety, Stress, and Coping: An International Journal, 8, 87100.

-2007.3 .2 受稿, 2007.9. 1 受理—— 